\title{
Market Segmentation of 92 Arab Banks
}

\author{
Suzanne Charbaji \\ American University of Beirut, Beirut, Lebanon \\ Email:sac03@mail.aub.edu
}

How to cite this paper: Charbaji, S. (2017) Market Segmentation of 92 Arab Banks. Open Journal of Accounting, 6, 71-81. https://doi.org/10.4236/ojacct.2017.63006

Received: April 25, 2017

Accepted: June 24, 2017

Published: June 27, 2017

Copyright $\odot 2017$ by author and Scientific Research Publishing Inc. This work is licensed under the Creative Commons Attribution International License (CC BY 4.0).

http://creativecommons.org/licenses/by/4.0/

\begin{abstract}
The aim of this paper is to conduct market segmentation of Arab banks and suggest a model to classify them into cohesive segments on the basis of their financial ratios as a guideline for future consolidation. Twelve financial ratios taken from Bankscope Database have been retrieved for 92 Arab banks for the year 2015. In view of the sensitivity of multivariate analysis to the normality assumption, it was decided to use the common log transformation. Factor analysis is used as a data reduction technique to find twelve financial ratios. Cluster analysis is then used to separate the 92 Arab banks into five different performance groups (segments). Multi-discriminant statistical analysis is used to answer the question: can a combination of financial ratios be used to predict bank's group membership? Findings of the study show that multidiscriminant analysis reveals that coverage ratio, profitability and efficiency separate the groups more widely than other financial ratios. The classification matrix shows that $98.9 \%$ of original banks are correctly classified. What's more, to go after a more efficient risk policy, this paper recommends merging big banks with small Arab banks that are less profitable, less efficient, and in weaker condition than their non-acquired peers in addition to merging huge banks operating in different Arab countries. Results of this study should provide insight for future researchers. Also, this piece of research bridges the gap between financial ratio analysis and multivariate statistical analysis for Arab banks.
\end{abstract}

\section{Keywords}

Market Segmentation, Risk Management, Financial Ratio Analysis, Bank Merger

\section{Introduction}

The impact of the global financial collapse which started in Fall 2008 and the decline in international oil prices was felt differently by different Arab countries (a mixture of complex heterogeneous reality). At the beginning of 2016, The 
Economist reported that "In the past 18 months the price has fallen by $75 \%$, from $\$ 110$ a barrel to below $\$ 27$. Yet this time the benefits are less certain. Although consumers have gained, producers are suffering grievously" (The Economist, 2016) [1]. On one hand, Arab oil-importing countries such as Egypt, Lebanon, Jordon, Morocco and Tunisia who subsidize their energy consumption felt that the fall in oil prices improve their fiscal balance. On the other hand, the biggest oil producer in the Middle East (GCC countries) partly felt that the decrease in oil prices harm their earnings. With billions of foreign assets and billions of cash reserves; the GCC countries are more immune to global crisis than non-GCC Arab countries. The IMF staffs believe that even though consequences of falling oil prices are manageable and provide an opportunity for taxation and fuel price reform in oil-importing as well as oil-exporting states, their negative aspect on credit risk is observed differently. What's more, "The rebalancing could result in modest upward pressures on global long-term real interest rates" (Husain et al., 2015: p. 31) [2]. During the oil price upturns from 1991 to mid 2014, the GCC region witnessed strong GDP and growth in government spending whereas during the falling oil prices after the mid of 2014, the GCC countries observed contractions in credit and reduction in the volume of equity markets in addition to automatic reduction in government spending. At the beginning, it wasn't visible that the global financial crisis will be a cause for alarm in Arab countries. Stock market in non-oil countries such as Jordon, Morocco and Lebanon was not affected as much as the stock market in the Gulf states. Besides, the Gulf countries which had accumulated a large part of the liquidity for the period of the boom years, came to the rescue and they did recapitalize some of the U.S. banks. "The Kuwait Investment Authority (KIA) and the Abu Dhabi Investment Authority, with the Singapore GIC and the Saudi prince Al-Waleed Bin Talal, put up 14.5 billion dollars to rescue Citigroup, while Kuwait also supplied funds to save Merrill Lynch. In February and June, Qatar also invested in Barclays and Credit Suisse, who then declared themselves bankrupt in September 2008, inflicting significant losses on the sovereign funds that had intended to secure them a few months earlier" (Orozco and Lesaca, 2009: p. 4) [3]. Khandelwal and his associates believe that "Strong banking sector soundness provides an important buffer in the GCC to the oil price decline since mid-2014. GCC banks have strong capital and liquidity buffers as of end-2014. Capital buffers and provisioning levels were above those in many other commodity exporting countries. NPL ratios are low and both loan loss provisions and profits are strong. In fact, provisions fully cover NPLs, on average" (Khandelwal, 2016: p. 5) [4]. What's more, low oil prices have decreased government expenditure and squeezed business expenses causing a rise in loan defaults. To empirically address this issue, this paper implements the cluster-base segmentation design in which five segments are determined on the basis of clustering 92 Arab banks on their twelve financial ratios. Based on review of literature it is found that since the original paper on market segmentation and product differentiation (Smith, 1956) [5], market segmentation research/analysis has been replaced by segmentation 
research. Previous research reveals that there are two tactics to conduct market segmentation-ex ante and ex post. The ex ante approach starts by investigating the motives that lead people to behave (Fennell 1997) [6]. The ex post approach focuses on what people must choose (Dickson, Farris and Verbeke, 2000) [7]. The discussion below focuses on market segmentation of Arab banks. First, the article highlights the significance of this paper, and then it turns the attention to data analysis and concludes the discussion with recommendations.

\section{The Significance of the Study}

The devastating impact of war in Yemen, Syria, Iraq, Libya and other Arab countries as well as the falling selling price of Brent crude oil from $\$ 114$ per Barrel in June 2014 to less than $\$ 50$ nowadays combined with the new Basel III capital regulations are all putting pressure on Arab banks to merge and create large entity able to survive the sudden crisis. "For Middle East banks, the biggest changes will come from the redefined capital requirements. The minimum CAR is expected to fall to anywhere between 15 and 18 percent, with SIFIs at the high end of that range. The higher requirements, combined with more stringent definitions of capital, mean that Middle East banks will need to raise substantially more capital" (Strategy \&, 2014: p. 8) [8]. To guard against the failure of smaller Arab banks during crisis, the researcher in this paper feels that it is imperative for Arab banks to increase efficiency, increase income from services, improve $\mathrm{ROE}$ and better restructure the loan portfolio of the acquired bank by merging Arab banks. A study such as the one suggested here is recommended by experts in this area. Deely argues that "Nearly every middle-market bank in the industry is looking to either acquire another bank or be acquired" (Deely, 2016) [9]. Marshall believes that “A small bank can't afford to have individuals knowledgeable about derivatives and isn't big enough to carry those risks......And big banks allow you to spread the costs of technology over a bigger customer base." (Marshall, 2016) [10]. So the big question that arises is to how to merge Arab banks? Augustine notes that “The Middle East's banking sector has been slow to adopt deep, transformative digitisation that other international players have started to embrace" (Augustine, 2016) [11].

\section{Purpose of the Study}

The aim of this paper is to conduct market segmentation of Arab banks and suggest a model to classify them into cohesive segments on the basis of their financial ratios as a guideline for future consolidation.

\section{Procedures and Methodology}

The variables used in this study are twelve financial ratios taken from Bankscope Database that have been retrieved for 92 Arab banks for the year 2015. In view of the sensitivity of multivariate analysis to the normality assumption, it was decided to use the common log transformation. Since it is too awkward to use all published financial ratios in comparing the performance of Arab banks and 
since it is more appropriate to get the same information from a smaller set of financial ratios, it was decided to use factor analysis as a data reduction technique to find twelve financial ratios. Kaisers-Meyer-Olkin (KMO) and Bartless test of sphericity were conducted in order to agree on the appropriateness of factor analysis. The (KMO) measure of sampling adequacy score of 0.610 was higher than the recommended level of 0.50 and the Bartless test of sphericity was significant (Chi Square $=1799.430, \mathrm{P}=0.00$ ), indicating that there are as much as necessary inter-correlations between the twelve financial ratios which permit the use of factor analysis. Principal axis factoring with oblique rotation was used as an extraction method. Four factors were extracted with the Eigen value above one criterion. The four factor solution accounted for 86.449 per cent of the total variance. The four factors are shown in Table 1.

Cluster analysis is then used to separate the 92 Arab banks into five different performance groups (segments).

\section{Classification of Arab Banks into Homogeneous Groups}

Inspecting the agglomeration schedule, which displays the similarity between two cases, reveals that it is better to stop the cluster analysis after step 87 (eliminating the last stages). Five clusters are revealed by stopping the clustering of 92 Arab banks at this point using twelve financial ratios. Group One consists of 33 banks as banks as shown in Table 2 .

Group Two consists of 45 banks as shown in Table 3.

Group Three consists of the following two banks in United Arab Emirates: Commercial Bank International P.S.C. and United Arab Bank PJSC. Group Four

Table 1. Structure matrix.

\begin{tabular}{ccccc}
\hline \multirow{2}{*}{ Structure Matrix ${ }^{1}$} & \multicolumn{4}{c}{ Component } \\
\cline { 2 - 5 } & 1 & 2 & 3 & 4 \\
\hline logcustomdep & 0.972 & 0.195 & 0.023 & -0.254 \\
$\log$ Equity & 0.971 & 0.226 & 0.293 & -0.232 \\
lognetintrev & 0.969 & 0.310 & 0.199 & -0.157 \\
logResimploan & 0.913 & 0.112 & 0.327 & 0.225 \\
Logliqassetmemo & 0.899 & 0.186 & -0.042 & -0.184 \\
logprofitBTax & 0.760 & 0.629 & 0.013 & -0.241 \\
Return.on.Average.Assets.(ROAA).\%. & 0.178 & 0.956 & 0.247 & -0.115 \\
Return.on.Average.Equity.(ROAE).\%. & 0.158 & 0.912 & -0.216 & -0.081 \\
Cost.to.Income.Ratio.\%. & -0.435 & -0.666 & -0.305 & 0.186 \\
Equity./.Assets.\%. & 0.015 & 0.214 & 0.837 & 0.010 \\
Loans./.Assets.\%. & 0.231 & -0.102 & 0.766 & 0.108 \\
logloanlosres & -0.155 & -0.092 & 0.049 & 0.989 \\
\hline
\end{tabular}

${ }^{1}$ Extraction Method: Principal Component Analysis. Rotation Mehod: Oblimin with Kaiser Normalization. Source: SPSS10. 
Table 2. Banks in group one.

\begin{tabular}{|c|c|c|}
\hline \multicolumn{3}{|c|}{ Banks in Group One } \\
\hline Country & Bank Name & Cluster Membership \\
\hline TUNISIA & Arab.Tunisian.Bank & 1 \\
\hline TUNISIA & Attijari.Bank & 1 \\
\hline TUNISIA & Union.Internationale.de.Banques & 1 \\
\hline QATAR & The.Commercial.Bank.(QSC) & 1 \\
\hline OMAN & Bank.Dhofar.SAOG & 1 \\
\hline OMAN & National.Bank.of.Oman.(SAOG) & 1 \\
\hline OMAN & Oman.Arab.Bank.SAOC & 1 \\
\hline MOROCCO & Banque.Marocaine.du.Commerce.Extérieur-BMCE.Bank & 1 \\
\hline MOROCCO & Banque.Marocaine.pour.le.Commerce.et.l'Industrie.BMCI & 1 \\
\hline MOROCCO & Crédit.Agricole.du.Maroc & 1 \\
\hline MOROCCO & Crédit.du.Maroc & 1 \\
\hline MOROCCO & Société.Générale.Marocaine.de.Banques & 1 \\
\hline LEBANON & B.L.C..Bank.S.A.L & 1 \\
\hline LEBANON & Bank.Audi.SAL & 1 \\
\hline LEBANON & Bank.of.Beirut.S.A.L. & 1 \\
\hline LEBANON & Bankmed,.sal & 1 \\
\hline LEBANON & Banque.Libano-Francaise & 1 \\
\hline LEBANON & BBAC.sal & 1 \\
\hline LEBANON & Byblos.Bank.S.A.L. & 1 \\
\hline LEBANON & Crédit.Libanais.S.A.L. & 1 \\
\hline LEBANON & CreditBank.SAL & 1 \\
\hline LEBANON & Fenicia.Bank.SAL & 1 \\
\hline LEBANON & Fransabank.sal & 1 \\
\hline LEBANON & Société.Générale.de.Banque.au.Liban.-.SGBL & 1 \\
\hline KUWAIT & Burgan.Bank.SAK & 1 \\
\hline JORDAN & Bank.of.Jordan.Plc & 1 \\
\hline JORDAN & Cairo.Amman.Bank & 1 \\
\hline JORDAN & Housing.Bank.for.Trade.\&.Finance.(The) & 1 \\
\hline JORDAN & Jordan.Commercial.Bank & 1 \\
\hline EGYPT & Arab.Banking.Corporation.-.Egypt.(SAE) & 1 \\
\hline BAHRAIN & Arab.Banking.Corporation.BSC-Bank.ABC & 1 \\
\hline BAHRAIN & BMI.Bank.BSC & 1 \\
\hline ALGERIA & Gulf.Bank.Algeria & 1 \\
\hline
\end{tabular}

Source: SPSS10.

consists of seven banks as shown in Table 4.

Group Five consists of five banks in Egypt: Bank of Alexandria, Commercial International Bank (Egypt).S.A.E., Credit Agricole Egypt SAE, Emirates National Bank of Dubai SAE and HSBC Bank Egypt S.A.E. 
Table 3. Banks in Group Two.

\begin{tabular}{|c|c|c|}
\hline \multicolumn{3}{|c|}{ Banks in Group Two } \\
\hline Country & Bank Name & Cluster Membership \\
\hline UNITED.ARAB.EMIRATES & Abu.Dhabi.Commercial.Bank & 2 \\
\hline UNITED.ARAB.EMIRATES & Bank.of.Sharjah & 2 \\
\hline UNITED.ARAB.EMIRATES & Commercial.Bank.of.Dubai.P.S.C. & 2 \\
\hline UNITED.ARAB.EMIRATES & Emirates.NBD.PJSC & 2 \\
\hline UNITED.ARAB.EMIRATES & First.Gulf.Bank & 2 \\
\hline UNITED.ARAB.EMIRATES & Mashreqbank.PSC & 2 \\
\hline UNITED.ARAB.EMIRATES & National.Bank.of.Abu.Dhabi & 2 \\
\hline UNITED.ARAB.EMIRATES & National.Bank.of.Fujairah.PJSC & 2 \\
\hline UNITED.ARAB.EMIRATES & $\begin{array}{l}\text { National.Bank.of.Ras.Al-Khaimah.(P.S.C.). } \\
\text { (The)-RAKBANK }\end{array}$ & 2 \\
\hline UNITED.ARAB.EMIRATES & National.Bank.of.Umm.Al-Qaiwain.PSC & 2 \\
\hline UNITED.ARAB.EMIRATES & Union.National.Bank & 2 \\
\hline SAUDI.ARABIA & Arab.National.Bank.Public.Joint.Stock.Company & 2 \\
\hline SAUDI.ARABIA & Banque.Saudi.Fransi.JSC & 2 \\
\hline SAUDI.ARABIA & National.Commercial.Bank.(The) & 2 \\
\hline SAUDI.ARABIA & Riyad.Bank & 2 \\
\hline SAUDI.ARABIA & Saudi.British.Bank.JSC.(The) & 2 \\
\hline SAUDI.ARABIA & Saudi.Hollandi.Bank & 2 \\
\hline QATAR & Ahli.Bank.QSC & 2 \\
\hline QATAR & Al.Khalij.Commercial.Bank & 2 \\
\hline QATAR & Doha.Bank & 2 \\
\hline QATAR & International.Bank.of.Qatar.Q.S.C. & 2 \\
\hline QATAR & Qatar.National.Bank & 2 \\
\hline OMAN & Bank.Muscat.SAOG & 2 \\
\hline MOROCCO & Banque.Centrale.Populaire.SA & 2 \\
\hline LEBANON & BLOM.Bank.s.a.l. & 2 \\
\hline LEBANON & IBL.Bank.sal & 2 \\
\hline LEBANON & Lebanon.\&.Gulf.Bank.S.A.L. & 2 \\
\hline KUWAIT & Al.Ahli.Bank.of.Kuwait.(KSC) & 2 \\
\hline KUWAIT & Commercial.Bank.of.Kuwait.K.P.S.C..(The) & 2 \\
\hline KUWAIT & Gulf.Bank.KSC.(The) & 2 \\
\hline KUWAIT & National.Bank.of.Kuwait.S.A.K. & 2 \\
\hline JORDAN & Jordan.Kuwait.Bank & 2 \\
\hline JORDAN & Société.générale.de.Banque-Jordanie & 2 \\
\hline EGYPT & Ahli.United.Bank.(Egypt).SAE & 2 \\
\hline EGYPT & Arab.African.International.Bank & 2 \\
\hline EGYPT & Banque.Misr.SAE & 2 \\
\hline EGYPT & BLOM.Bank.Egypt.SAE & 2 \\
\hline EGYPT & Egyptian.Gulf.Bank.SAE & 2 \\
\hline EGYPT & National.Bank.of.Egypt & 2 \\
\hline EGYPT & Société.Arabe.Internationale.de.Banque-SAIB & 2 \\
\hline EGYPT & Union.National.Bank.-.Egypt.SAE & 2 \\
\hline BAHRAIN & Ahli.United.Bank.BSC & 2 \\
\hline BAHRAIN & BBK.B.S.C. & 2 \\
\hline BAHRAIN & Future.Bank.B.S.C. & 2 \\
\hline BAHRAIN & National.Bank.of.Bahrain & 2 \\
\hline
\end{tabular}

Source: SPSS10. 
Table 4. Banks in group four.

\begin{tabular}{ccc}
\hline & Banks in Group Four & \\
\hline Country & Bank Name & Cluster Membership \\
\hline TUNISIA & Arab.Banking.Corporation.-.Tunisie & 4 \\
OMAN & HSBC.Bank.Oman & 4 \\
LEBANON & Banque.BEMO.Sal & 4 \\
LEBANON & Banque.Misr.Liban & 4 \\
JORDAN & Arab.Bank.Plc & 4 \\
JORDAN & Jordan.Ahli.Bank.Plc & 4 \\
BAHRAIN & Gulf.International.Bank.BSC & 4 \\
\hline
\end{tabular}

Source: SPSS10.

\section{Assessing the Relative Importance of the Discriminant Financial Ratios}

Multi-discriminant statistical analysis is used to answer the question: can a combination of financial ratios be used to predict bank's group membership? It is employed in order to evaluate the relative importance of the financial ratios (independent variables) to the discriminant functions. The question that arises is whether the 92 Arab banks that are divided into five segments can be differentiated on the basis of their twelve financial ratios. The standardized multiple discriminant coefficients in Table 5 are similar to the beta weights in multiple regression: they show the relative significance of financial ratios in predicting bank's group membership. The larger the standardized coefficient, the greater is the contribution of the financial ratio to the discrimination between clusters of Arab banks. Besides, Table 5 shows that the first function provides the most overall discrimination between clusters of banks, the second provides second most, and so on.

The structure matrix shows the correlations of each financial ratio with all discriminant functions. Theses correlations are similar to factor loadings in factor analysis; that is, they help in naming the discriminating function. Results of multi-discriminant statistical analysis in this study reveal that coverage ratio, profitability and efficiency separate the banks more widely than other financial ratios. Since there are five groups, four equations are extracted.

Table 6 shows how well the classification functions predict bank's membership. The classification matrix shows that $98.9 \%$ of original banks are correctly classified. Just one bank "The Commercial Bank (QSC)" in Qatar was wrongly classified in Group I and it is predicted to be a member of Group (II).

\section{Conclusions}

Table 7 shows that the five groups of banks differ in risk, profitability and efficiency.

Group (II) has the highest Reserves for Impaired Loans/NPLs th USD. This means that Group (II) has the best coverage ratio taken as provisions for bad 
Table 5. Standardized canonical discriminant function coefficients.

\begin{tabular}{ccccc}
\hline \multirow{2}{*}{$\begin{array}{c}\text { Standardized Canonical Discriminant } \\
\text { Function Coefficients }\end{array}$} & \multicolumn{4}{c}{ Function } \\
\cline { 2 - 5 } Logcustomdep & 0.601 & -0.970 & -0.531 & 0.134 \\
logEquity & 1.512 & 2.340 & 1.379 & 1.399 \\
Lognetintrev & -0.045 & -1.987 & 2.505 & 0.124 \\
logprofitBTax & 0.363 & 0.535 & -1.506 & 0.198 \\
Logliqassetmemo & -0.143 & -0.305 & 0.336 & 1.120 \\
Logloanlosres & 0.994 & -0.093 & 1.195 & 1.792 \\
logResimploan & -2.384 & 0.607 & -2.747 & -3.431 \\
Return.on.Average.Assets.(ROAA).\%. & -0.109 & 0.104 & -0.725 & 1.528 \\
Return.on.Average.Equity.(ROAE).\%. & -0.421 & 0.924 & 1.134 & -1.169 \\
Cost.to.Income.Ratio.\%. & 0.875 & 0.655 & 0.267 & -0.117 \\
Equity./.Assets.\%. & -0.111 & -0.169 & 0.121 & -2.362 \\
Loans./.Assets.\%. & 0.591 & -0.354 & 0.633 & 1.890 \\
\hline
\end{tabular}

Source: SPSS10.

Table 6. Classification results ${ }^{1}$.

\begin{tabular}{cccccccc}
\hline & $\begin{array}{c}\text { Cluster } \\
\text { Number } \\
\text { of Case }\end{array}$ & 1 & 2 & 3 & 4 & 5 & Total \\
\cline { 1 - 3 } Original Count & 1 & 32 & 1 & 0 & 0 & 0 & 33 \\
& 2 & 0 & 45 & 0 & 0 & 0 & 45 \\
& 3 & 0 & 0 & 2 & 0 & 0 & 2 \\
& 4 & 0 & 0 & 0 & 7 & 0 & 7 \\
& 5 & 0 & 0 & 0 & 0 & 5 & 5 \\
& 1 & 97 & 3.0 & 0 & 0 & 0 & 100 \\
& 2 & 0 & 100 & 0 & 0 & 0 & 100 \\
& 3 & 0 & 0 & 100 & 0 & 0 & 100 \\
& 4 & 0 & 0 & 0 & 100 & 0 & 100 \\
& 5 & 0 & 0 & 0 & 0 & 100 & 10 \\
\hline
\end{tabular}

${ }^{1} 98.9 \%$ of original grouped cases correctly classified. Source: SPSS10.

debt divided by non-performing loans. Banks in other segments are provisioning a smaller amount for their bad debt. The possibility of merger between banks in Group (II) and banks in the other groups should turn out to be one of the solutions for going after a more efficient risk policy. Group (II) has the highest Equity which enables banks in Group (II) to get more benefits when times are good and they can rely on a mixture of government support when choices go wrong. It seems that management in banks outside Group (II) believe that their banks can gain generous benefits from funding with debt rather than equity (for 
Table 7. The average financial ratio of the five segments of Arab banks.

\begin{tabular}{|c|c|c|c|c|c|c|}
\hline & & $\begin{array}{c}\text { Cost to Income } \\
\text { Ratio \% }\end{array}$ & $\begin{array}{l}\text { Equity } \\
\text { th USD }\end{array}$ & $\begin{array}{l}\text { Net Interest } \\
\text { Revenue } \\
\text { th USD }\end{array}$ & $\begin{array}{l}\text { Reserves for } \\
\text { Impaired } \\
\text { Loans/NPLs } \\
\text { th USD }\end{array}$ & $\begin{array}{c}\text { Loan Loss } \\
\text { Reserve/Gross } \\
\text { Loans } \% .\end{array}$ \\
\hline \multirow{2}{*}{ All Banks } & $\mathrm{N}$ & 92 & 92 & 92 & 92 & 92 \\
\hline & Mean & 43.45 & 2497660.74 & 517079.77 & 452981.41 & 4.68 \\
\hline \multirow{2}{*}{ Group One } & $\mathrm{N}$ & 33 & 33 & 33 & 33 & 33 \\
\hline & Mean & 51.20 & 1179976.88 & 257823.61 & 249815.48 & 5.05 \\
\hline \multirow{2}{*}{ Group Two } & $\mathrm{N}$ & 45 & 45 & 45 & 45 & 45 \\
\hline & Mean & 34.47 & $3,913,078.36$ & 778928.89 & 673951.65 & 4.23 \\
\hline \multirow{2}{*}{$\begin{array}{l}\text { Group } \\
\text { Three }\end{array}$} & $\mathrm{N}$ & 2 & 2 & 2 & 2 & 2 \\
\hline & Mean & 47.20 & $660,762.42$ & 201865.21 & 220435.67 & 5.73 \\
\hline \multirow{2}{*}{$\begin{array}{c}\text { Group } \\
\text { Four }\end{array}$} & $\mathrm{N}$ & 7 & 7 & 7 & 7 & 7 \\
\hline & Mean & 70.21 & 1272211.36 & 195891.89 & 215974.85 & 4.80 \\
\hline \multirow{2}{*}{ Group Five } & $\mathrm{N}$ & 5 & 5 & 5 & 5 & 5 \\
\hline & Mean & 34.13 & $906,004.07$ & 447277.14 & 229971.82 & 5.66 \\
\hline
\end{tabular}

instance interest payments on their debt are tax-deductible) whereas banks in Group (II) retain their earnings to reinforce equity on the balance sheet (without anything taken from shareholders who still be the owner of this equity). In fact, risky activities are funded with plenty of equity rather than too much debt. What's more, it seems that banks in Group (II) are more in line with the minimum total capital requirements under Basel III. Banks in Group (II) have focused on protecting their depositors and increased their tier 1 capital (the bank's required reserves of shareholders' equity and retained earnings) as compared to their tier 2 capital (bank's supplementary capital). We can conclude that banks in Group (II) enjoy a better financial strength from a regulator's viewpoint, because Tier 1 capital is the perfect form of a bank's capital (the money the bank has accumulated to keep it utilized all the way through the risky transactions). In addition, banks in Group (II) are better placed to capitalize on higher return businesses than banks in other segments. The average net interest revenue (the difference between interest earned from borrowers on their loans and interest paid to other banks or to individuals with deposits at the bank (lenders)) in Group (II) is higher than other banks. Since net interest income is the major source of revenue for banks, we conclude that banks in Group (II) have better lending opportunities than Arab banks in the other groups. Using the efficiency ratio (cost to income ratio) reveals that banks in Group (II) and banks in group (V) are the most efficient having the lowest cost to income ratio. It is highly recommended that banks in Group III, IV and partly banks in Group I focus on activities that put together value and help them cut costs, improve customer service, and enhance customer retention. Both bank's performance (measured by net interest revenue) and bank's efficiency (measured by low cost to income ratio 
and low non performing loans) will improve and the benefits will increase. It is imperative to note here that in their attempt to guard against the regional economic slump, Arab banks are merging into larger banks. Gambrell notes that "Shareholders at the National Bank of Abu Dhabi and First Gulf Bank approved the tie-up at two separate meetings, a move first publicly discussed by the two financial firms in June" (Gambrell, 2016) [12]. Wam reported that "Shareholders in First Gulf Bank PJSC (FGB) and National Bank of Abu Dhabi, NBAD, have approved a proposed merger of the two banks, which will create the largest financial institution in the United Arab Emirates, UAE, with assets of approximately AED655 billion (US\$178 billion)" (Wam, 2016) [13]. In addition, Gulfbusiness also reported that Blom bank signed an agreement to acquire HSBC bank in Lebanon. "This acquisition falls under Blom Bank's strategy of expanding its customer base and diversifying its assets and revenues. The transaction will help Blom Bank expand its corporate and commercial businesses as well as its retail activities" (Gulfbusiness, 2016) [14]. This paper recommends merging big Arab banks with small Arab banks that are less profitable, less efficient, and in weaker conditions in local Arab markets in addition to merging huge banks operating in different Arab countries (so merge does not harm consumers by reducing competition between local big banks). After all, Arab banks need to catch up with global peers.

\section{References}

[1] The Economist (2016) The World Economy: Who's Afraid of Cheap Oil? http://www.economist.com/news/leaders/21688854-low-energy-prices-ought-be-sh ot-arm-economy-think-again-whos-afraid-cheap

[2] Husain, A.M., Arezki, R., Breuer, P., Haksar, V., Helbling, T., Medas, P., Sommer, M. and an IMF Staff Team (2015) Global Implications of Lower Oil Prices. International Monetary Fund. https://www.imf.org/external/pubs/ft/sdn/2015/sdn1515.pdf

[3] Orozco, O. and Lesaca, J. (2009) Impact of the Global Economic Crisis in Arab Countries: A First Assessment. Casa Árabe. http://www.clubmadrid.org/img/secciones/Background_Doc_ArabWorld_Eng.pdf

[4] Khandelwal, P. Miyajima, K. and Santos, A. (2016) The Impact of Oil Prices on the Banking System in the GCC", IMF Working Papers WP/16/161. International Monetary Fund. https://www.imf.org/external/pubs/ft/wp/2016/wp16161.pdf

[5] Smith, W. (1956) Product Differentiation and Market Segmentation as Alternative Marketing Strategies. Journal of Marketing, 21, 3-8. https://doi.org/10.2307/1247695

[6] Fennell, M. (1997) Low Self-Esteem: A Cognitive Perspective. Behavioural and Cognitive Psychotherapy, 25, 1-26. https://doi.org/10.1017/S1352465800015368

[7] Dickson, P.R., Farris, P.W. and Verbeke, W.J.M.I. (2000) Dynamic Strategic Thinking. Journal of the Academy of Marketing Science, 29, 216-237. https://doi.org/10.1177/0092070301293001

[8] Strategy\&-Formerly Booz \& Company (2014) Basel III: A Silver Lining for Middle East Banks.

http://www.strategyand.pwc.com/media/file/Basel-III_A-silver-lining-for-Middle-E ast-banks.pdf 
[9] Deely, M. (2016) The Benefits (and Dangers) of Bank Mergers and Acquisitions. http://www.bigskyassociates.com/blog/the-benefits-and-dangers-of-bank-mergers-a nd-acquisitions\#sthash.EqG07NIF.dpuf

[10] Marshall, J. (1998) Why Banks Feel Urge to Merge. SFGATE. http://www.sfgate.com/business/article/Why-Banks-Feel-Urge-To-Merge-3009357. php

[11] Augustine, B.D. (2016) Mideast Banks Play Catch up in Digitisation Game. GULF NEWS: Banking. http://gulfnews.com/business/sectors/banking/mideast-banks-play-catch-up-in-digi tisation-game-1.1673898

[12] Gambrell, J. (2016) 2 Abu Dhabi Banks to Merge into Largest Gulf Arab Bank. AP Radio News.

http://bigstory.ap.org/article/bc5b62c791a74c66a3297744cc5cadb7/2-abu-dhabi-ban ks-merge-largest-gulf-arab-bank

[13] Wam (2016) FGB and NBAD Shareholders Approve Merger to Create UAE's Largest Bank. Emirates Business 24/7.

https://en.wikipedia.org/wiki/Emirates_Business_24/7

[14] Gulfbusiness (2016) Blom Bank to Acquire HSBC’s Lebanese Business. http://gulfbusiness.com/blom-bank-acquire-hsbcs-lebanese-business/

Submit or recommend next manuscript to SCIRP and we will provide best service for you:

Accepting pre-submission inquiries through Email, Facebook, LinkedIn, Twitter, etc. A wide selection of journals (inclusive of 9 subjects, more than 200 journals) Providing 24-hour high-quality service User-friendly online submission system Fair and swift peer-review system Efficient typesetting and proofreading procedure Display of the result of downloads and visits, as well as the number of cited articles Maximum dissemination of your research work

Submit your manuscript at: http://papersubmission.scirp.org/

Or contact ojacct@scirp.org 